\title{
Optimising neuroimaging effectiveness in a district general hospital
}

\author{
${ }^{1} \mathrm{MO}$ McCarron, ${ }^{2} \mathrm{C}$ Wade, ${ }^{3} \mathrm{P}$ McCarron \\ ${ }^{1}$ Consultant Neurologist, Department of Neurology, Altnagelvin Hospital, Derry; ${ }^{2}$ Medical Secretary, Department of Neurology, Altnagelvin \\ Hospital, Derry; ${ }^{3}$ Professor, Department of Public Health Medicine and Epidemiology, Queen's University, Belfast, UK
}

\section{ABSTRACT}

Background: Diagnostic accuracy in neurology frequently depends on clinical assessment and neuroimaging interpretation. We assessed neuroimaging discrepancy rates in reported findings between general radiologists and neuroradiologists among patients from a district general hospital (DGH).

Methods: A neuroradiologist's report was sought on selected DGH patients over 28 months. Pre-planned outcomes included comparisons of primary findings (main diagnosis or abnormality), secondary findings (differential diagnoses and incidental findings) and advice from neuroradiologists for further investigations.

Results: A total of 233 patients (II 9 men and I I 4 women), mean age 47.2 (SD 17.8) years were studied: 43 had a computed tomography (CT) brain scan only, 37 had CT and magnetic resonance imaging (MRI) scans and 153 had only MRI scans. Discrepancies in the primary diagnosis/abnormality were identified in 33 patients (14.2\%). This included 7 of 43 patients (16.3\%) who had a CT brain scan as their only neuroimaging. Secondary outcomes differed in 50 patients (21.5\%). Neuroradiologists recommended further neuroimaging for 29 patients (12.4\%). The most common discrepancies in the primary diagnosis/abnormality were misinterpreting normal for hippocampal sclerosis and missed posterior fossa lesions. There was no evidence of temporal changes in discrepancy rates.

Conclusions: Selecting CT and MR neuroimaging studies from general hospitals for reviewing by neuroradiologists is an important and effective way of optimising management of neurological patients.

KEYWORDS Neuroimaging, district general hospital, neurology, effectiveness

\author{
Correspondence to $\mathbf{M} \mathbf{M c C a r r o n}$ \\ Department of Neurology \\ Altnagelvin Hospital \\ Derry BT47 6SB \\ $N$ Ireland \\ tel. $+44(0) 287|345| 7 \mid$ \\ e-mail \\ markmccarron@doctors.org.uk
}

DECLARATION OF INTERESTS No conflicts of interest declared.

\section{INTRODUCTION}

As neuroimaging technology advances, improvements in patient diagnosis and management with quality-assured reporting of findings should follow. However, human error is inevitable in medicine, including radiology; discrepancies occur in 2-20\% of reports.' Unlike many physical signs, radiology scans remain unchanged and can be retrieved and reviewed to provide second opinions and assess discrepancy rates. ${ }^{2,3}$ With increasing emphasis on patient safety and processes of care, ${ }^{4-8}$ frameworks for addressing radiological discrepancies in a formative process with educational feedback are emerging. ${ }^{9,10}$

\section{BACKGROUND}

Changes in different aspects of healthcare can have numerous consequences, which initially may not be anticipated. For example, in the UK one result of the European working time directive and modernising medical careers on NHS resources was the introduction of the role of physician assistant, as currently exists in the USA." In the same way, increasing numbers of magnetic resonance imaging (MRI) scanners and the rise in the number of neurologists working in district general hospitals (DGH) in the UK have triggered an evaluation of the role of neurologists ${ }^{12}$ and the assessment of the quality of neuroimaging reports provided by general radiologists. ${ }^{2}$ The appointment of a neurologist in our DGH (along with informal opinions of other neuroradiologists in our organisation) prompted a systematic examination of the quality assurance processes related to local neuroimaging reports and the potential usefulness of a second reporting system from neuroradiologists. We consider this an important issue as many neurological inpatients in the UK are managed in DGHs.

Measuring the effectiveness of a service is a recognised aspect of assessing service quality. ${ }^{13}$ We previously measured neuroimaging discrepancies in a DGH and completed an audit cycle..$^{14,15}$ In the current update, we report: (i) neuroimaging discrepancy rates for 2007-9; 
(ii) trends in discrepancy rates to measure the ongoing impact of a second reporting service; and (iii) identify recurrent areas of discrepancies and features of the service amenable to development.

\section{METHODS}

Neurological patients with any neuroimaging (computed tomography [CT] of brain or MRI of brain or spine) and attending one neurologist from I January 2007 until 30 April 2009 were eligible for involvement in this study if a second report on the neuroimaging was requested. The initial report came from general radiologists in the $\mathrm{DGH}$ and the second report from neuroradiologists working at a tertiary referral hospital. Selection criteria for an opinion from a neuroradiologist remained constant between the studies ${ }^{14,15}$ and included the following: (i) a report from a general radiologist recommending a neuroradiologist's opinion; (ii) after personally reviewing the neuroimaging there was concern on the part of the neurologist about the presence or nature of a structural abnormality; (iii) doubt from the neurologist of the reported differential diagnosis or lack of diagnosis from the report provided by general radiologists. This last indication included reports from general radiologists in which refinement of the differential diagnosis was deemed desirable.

Four neuroradiologists provided written second opinion reports. They had worked between two and 24 years as consultant neuroradiologists. The 20 general radiologists had worked between three and 21 years as consultant radiologists. Two general radiologists performed doublereporting. They provided a report consensus after both had individually studied the neuroimaging. The neurologist's workload remained stable.

\section{OUTCOME MEASURES}

\section{Primary outcome}

The primary outcome measure was the frequency of disagreement between neuroradiologists and general radiologists in the primary diagnosis/abnormality of each report.

\section{Secondary outcomes}

Incidental findings such as brain atrophy, pineal or arachnoid cysts and differences in differential diagnoses were all categorised as secondary findings. Other secondary outcomes included the frequency of combined disagreements in primary and secondary findings, the proportion of patients in whom neuroradiologists recommended additional neuroimaging investigations, which had not been mentioned by general radiologists, and the frequency of disagreement in the primary diagnosis/abnormality in patients with CT brain-only imaging. As we were aware of anecdotal evidence that discrepancies in reporting CT brain scans had occurred, we were prompted to perform this subgroup analysis. Discrepancies were itemised and classified as: missed abnormality, normal misinterpreted as abnormal, or misinterpreted lesions (e.g. perivascular space misinterpreted as an infarct). Location of discrepancies (hemisphere, posterior fossa, or spinal) was recorded. Details of abnormal vessels were also recorded.

The results were then compared with two previous studies $^{14,15}$ and with an independent study from neuroradiologists working in Northern Ireland. ${ }^{2}$

\section{STATISTICAL ANALYSES}

The number and proportion of patients in whom neuroimaging discrepancies were identified by neuroradiologists were calculated with $95 \%$ confidence intervals $(\mathrm{Cl})$ for the proportions, using the Wilson procedure with a correction for continuity. The Fisher exact test was used for comparing categorical values.

\section{RESULTS}

Of 233 patients there were II 9 men and II 4 women, mean age 47.2 (SD 17.8) years; 43 patients had CT brain scans only, I53 had MRI brain and/or spine scans only and 37 had both CT and MRI scans. Primary diagnosis/ abnormality discrepancies were identified in 33 patients (14.2\%). Secondary outcomes including secondary findings or differential diagnosis discrepancies, CT-only primary diagnosis/abnormality discrepancies and the frequency of further recommended neuroradiological investigations are listed in Table I. The individual itemised primary diagnosis/abnormality discrepancies

TABLE I Discrepancy outcomes in neuroimaging

\begin{tabular}{|l|c|c|}
\hline \multicolumn{1}{|c|}{ Outcomes } & \% (number) & $\begin{array}{c}\text { 95\% confidence } \\
\text { intervals }\end{array}$ \\
\hline $\begin{array}{l}\text { Differences in } \\
\text { primary diagnosis/ } \\
\text { abnormality }\end{array}$ & $14.2(33)$ & $10.1-19.5$ \\
\hline $\begin{array}{l}\text { Secondary finding/ } \\
\text { differential } \\
\text { diagnosis }\end{array}$ & $21.5(50)$ & $16.5-27.4$ \\
\hline $\begin{array}{l}\text { Primary or } \\
\text { secondary finding } \\
\text { differences }\end{array}$ & $33.5(78)$ & $27.5-40.0$ \\
\hline $\begin{array}{l}\text { Further } \\
\text { investigation } \\
\text { recommended }\end{array}$ & $12.4(29)$ & $8.6-17.6$ \\
\hline $\begin{array}{l}\text { Computed } \\
\text { tomography-only } \\
\text { patients primary } \\
\text { finding differences }\end{array}$ & $16.3(7$ of 43$)$ & $7.3-31.3$ \\
\hline
\end{tabular}


TABLE 2 Itemised discrepancies between the general radiologist's diagnosis and that of the neuroradiologists

\begin{tabular}{|c|c|}
\hline General radiologist finding & Neuroradiologist finding \\
\hline \multicolumn{2}{|c|}{ Magnetic resonance imaging } \\
\hline \multicolumn{2}{|l|}{ Cerebrovascular } \\
\hline $\begin{array}{l}\text { Strongly suggests multiple } \\
\text { sclerosis }\end{array}$ & $\begin{array}{l}\text { Cystic infarcts in basal } \\
\text { ganglia and pons }\end{array}$ \\
\hline Arteriovenous malformation & $\begin{array}{l}\text { Chronic left transverse sinus } \\
\text { thrombosis }\end{array}$ \\
\hline $\begin{array}{l}\text { Haemorrhage due to an } \\
\text { angioma }\end{array}$ & $\begin{array}{l}\text { Right frontal infarct and } \\
\text { ischaemia }\end{array}$ \\
\hline Normal & $\begin{array}{l}\text { Left superior and middle } \\
\text { temporal gyri cystic infarcts }\end{array}$ \\
\hline $\begin{array}{l}\text { Normal magnetic resonance } \\
\text { imaging (MRI) brain and MR } \\
\text { venography }\end{array}$ & $\begin{array}{l}\text { Abnormal left internal } \\
\text { jugular vein }\end{array}$ \\
\hline $\begin{array}{l}\text { No pontine lesions } \\
\text { mentioned }\end{array}$ & Cystic pontine infarcts \\
\hline Normal & $\begin{array}{l}\text { Right internal carotid artery } \\
\text { dissection }\end{array}$ \\
\hline Right thalamic gliosis & $\begin{array}{l}\text { Bilateral cerebellar, right } \\
\text { thalamic and acute vermian } \\
\text { infarctions }\end{array}$ \\
\hline \multicolumn{2}{|l|}{ Inflammatory } \\
\hline Small localized syrinx & $\begin{array}{l}\text { Long-standing cervical lesion } \\
\text { probably inflammatory }\end{array}$ \\
\hline Mid-brain glioma & $\begin{array}{l}\text { Left medial longitudinal } \\
\text { fasciculus inflammatory } \\
\text { demyelination }\end{array}$ \\
\hline \multicolumn{2}{|l|}{ Normal } \\
\hline $\begin{array}{l}\text { Right temporal postictal } \\
\text { oedema }\end{array}$ & Normal \\
\hline $\begin{array}{l}\text { Bilateral uncus/hippocampus } \\
\text { postictal oedema }\end{array}$ & Normal \\
\hline $\begin{array}{l}\text { Possible right hippocampal } \\
\text { sclerosis }\end{array}$ & Normal \\
\hline $\begin{array}{l}\text { Right postictal oedema or } \\
\text { mesial sclerosis }\end{array}$ & Normal \\
\hline Mesial temporal sclerosis & $\begin{array}{l}\text { Normal medial temporal } \\
\text { lobes }\end{array}$ \\
\hline $\begin{array}{l}\text { Hyperintense conus - } \\
\text { transverse myelitis }\end{array}$ & Normal cauda equina \\
\hline \multicolumn{2}{|l|}{ Infection } \\
\hline $\begin{array}{l}\text { Infarctions with high } \\
\text { probability of frontal abscess }\end{array}$ & $\begin{array}{l}\text { Infarctions secondary to } \\
\text { meningitis }\end{array}$ \\
\hline $\begin{array}{l}\text { New lesions not related to } \\
\text { meningitis }\end{array}$ & $\begin{array}{l}\text { Old brain changes from } \\
\text { bacterial meningitis }\end{array}$ \\
\hline \multicolumn{2}{|l|}{ Tumour } \\
\hline $\begin{array}{l}\text { No skull vault metastases } \\
\text { mentioned }\end{array}$ & Skull vault metastases \\
\hline \multicolumn{2}{|l|}{ Miscellaneous } \\
\hline Mild tonsillar herniation & $\begin{array}{l}\text { Retroflexed odontoid peg. } \\
\text { No tonsillar herniation }\end{array}$ \\
\hline
\end{tabular}

\begin{tabular}{|c|c|}
\hline General radiologist finding & Neuroradiologist finding \\
\hline Normal & $\begin{array}{l}\text { Right cerebral destructive } \\
\text { lesion }\end{array}$ \\
\hline $\begin{array}{l}\text { No intracranial } \\
\text { enhancement }\end{array}$ & $\begin{array}{l}\text { Features of intracranial } \\
\text { hypotension }\end{array}$ \\
\hline $\begin{array}{l}\text { Non-obstructive } \\
\text { hydrocephalus }\end{array}$ & $\begin{array}{l}\text { Obstructive hydrocephalus } \\
\text { with colloid cyst }\end{array}$ \\
\hline Hippocampal sclerosis & $\begin{array}{l}\text { Cyst at lateral end of } \\
\text { hippocampal sulcus }\end{array}$ \\
\hline $\begin{array}{l}\text { Multiple sclerosis lesions } \\
\text { periventricularly perpendicular } \\
\text { to ventricle, corpus callosum, } \\
\text { right mid brain }\end{array}$ & $\begin{array}{l}\text { Thalamic change } \\
\text { suspicious for Wernicke } \\
\text { encephalopathy and non- } \\
\text { specific nodular lesions }\end{array}$ \\
\hline Normal & $\begin{array}{l}\text { Acute hypoxic ischaemic } \\
\text { encephalopathy or carbon } \\
\text { monoxide poisoning }\end{array}$ \\
\hline \multicolumn{2}{|l|}{ Computed tomography-only } \\
\hline \multicolumn{2}{|l|}{ Cerebrovascular } \\
\hline No focal brain lesion & $\begin{array}{l}\text { Subcortical white matter } \\
\text { lesions }\end{array}$ \\
\hline Haemorrhagic infarct & $\begin{array}{l}\text { Left frontal intracerebral } \\
\text { haemorrhage, probably } \\
\text { cerebral amyloid angiopathy }\end{array}$ \\
\hline Normal & $\begin{array}{l}\text { Left posterior parietal } \\
\text { ischaemia or trauma }\end{array}$ \\
\hline Right basal ganglia infarct & $\begin{array}{l}\text { Right inferior basal ganglia } \\
\text { perivascular space }\end{array}$ \\
\hline No focal lesion & $\begin{array}{l}\text { Middle cerebral artery dot } \\
\text { sign }\end{array}$ \\
\hline Normal & $\begin{array}{l}\text { Ischaemic pons and focus in } \\
\text { right occipital lobe }\end{array}$ \\
\hline \multicolumn{2}{|l|}{ Normal } \\
\hline $\begin{array}{l}\text { Ischaemic left basal ganglia, } \\
\text { external capsule and insula }\end{array}$ & Normal \\
\hline
\end{tabular}

are listed in Table 2.Illustrative examples of discrepancies in the primary diagnosis/abnormality category are shown in Figure IA-C.

The location and type of discrepancies among primary diagnoses/abnormalities are listed in Table 3. One-third of discrepancies occurred from vascular, spinal or posterior fossa lesions. Missed lesions, misinterpretation of abnormalities and misinterpretation of normal structures as abnormal were distributed in similar proportions. Recurring disagreements included misinterpretation of hippocampal architecture or cysts as hippocampal sclerosis or postictal oedema $(n=6)$ and missed posterior fossa lesions $(n=3)$. Double reporting by some general radiologists reduced but did not eliminate primary finding discrepancies $(9 \%, 95 \% \mathrm{Cl}$, $2 \%-30 \%$ versus $15 \%, 95 \% \mathrm{Cl}, 10 \%-20 \%, p=0.55)$. The neurologist had requested a neuroradiologist's report in 31 of the identified 33 primary discrepancies while general radiologists had suggested a neuroradiologist's report in the other two patients. 


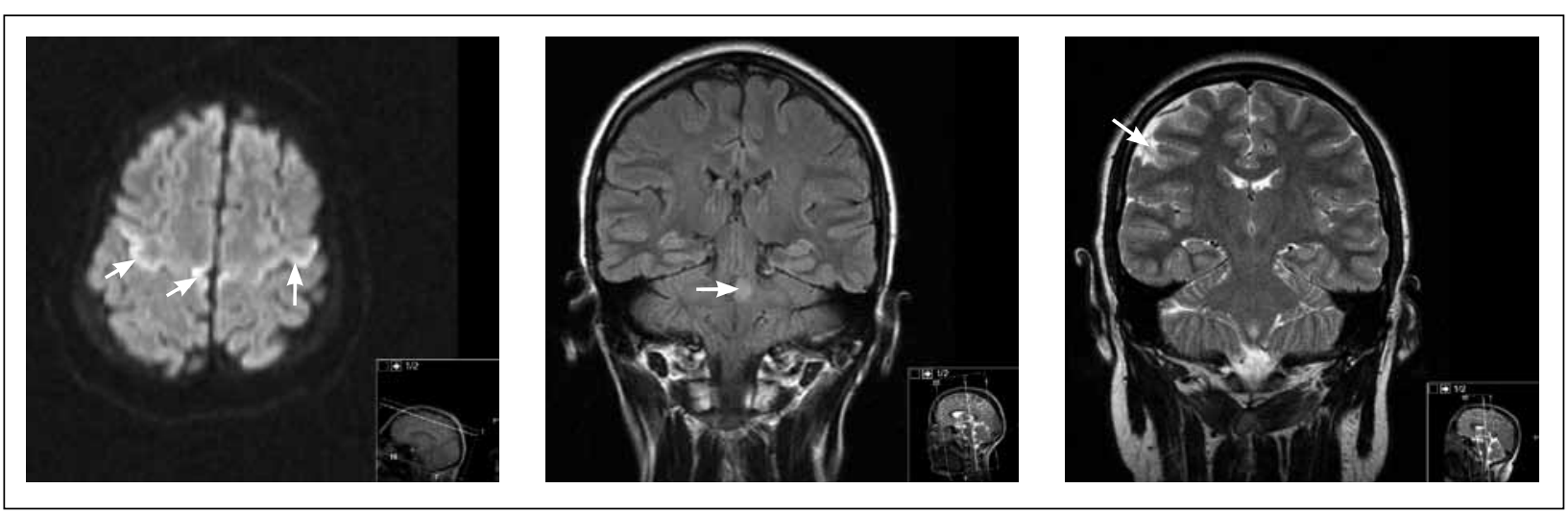

FIGURE IA-C (A) Missed hypoxic ischaemic change bilaterally demonstrated on axial diffusion weighted imaging magnetic resonance imaging (MRI) scan of brain (arrows). (B) Demyelination in left pons - misinterpreted as possible glioma on coronal T2-FLAIR image (arrow). (C) Missed destructive right cortical lesion demonstrated on coronal T2 MRI scan (arrow).

TABLE 3 Reporting and neuroradiological characteristics among 33 primary finding discrepancies

\begin{tabular}{|l|c|}
\hline Characteristic & Number (\%) \\
\hline Category of discrepancy & $22(67)$ \\
\hline Supratentorial & $5(15)$ \\
\hline Posterior fossa & $2(6)$ \\
\hline Spine & $4(12)$ \\
\hline Vascular (vessel only) & \multicolumn{2}{|l|}{} \\
\hline Type of discrepancy & $12(36)$ \\
\hline Missed abnormality & $10(33)$ \\
\hline Misinterpreted abnormality & Normal misinterpreted as abnormal \\
\hline $\begin{array}{l}\text { Primary discrepancies and number of reporting general } \\
\text { radiologists }\end{array}$ & 3 I of $210(15)$ \\
\hline Single reporter & 2 of $23(9)^{*}$ \\
\hline Double general radiologist & 20 \\
\hline Radiology personnel & \\
\hline $\begin{array}{l}\text { Total number of reporting general } \\
\text { radiologists }\end{array}$ & 4 \\
\hline Total number of neuroradiologists & \\
\hline${ }^{*} \chi^{2}$ test p=0.55 & \\
\hline
\end{tabular}

The findings of this study and two previous studies are summarised in Figure 2. Overlapping confidence intervals demonstrate little change in the discrepancy rate of primary and secondary findings with time. Additional investigations were consistently recommended by neuroradiologists in more than $10 \%$ of patients. The results of these studies are comparable to an independent study of second opinions performed independently by neuroradiologists working in Northern Ireland. ${ }^{2}$

\section{DISCUSSION}

This study demonstrated that selected second reporting from neuroradiologists can improve diagnostic accuracy and optimise management of neurological patients in a $\mathrm{DGH}$. Multidisciplinary involvement as recorded in previous studies ${ }^{2,14,15}$ continues to yield similar efficacy in revising reports and justifies the local neurology/ radiology investment in this exercise. The effectiveness of a service is a recognised feature of quality.

The published literature has many reports of very low discrepancy rates between general or trainee radiologists and neuroradiologists. ${ }^{16}$ In a large study in the US of over 2,000 scans, clinically relevant discrepancies were reported in just $1.8 \%$ among faculty neuroradiologists. ${ }^{17}$ Clinically relevant discrepancies have a similarly low frequency rate of less than $2 \%$ in many radiology subspecialties. ${ }^{18}$ In addition, in a stroke study doublereading of $\mathrm{CT}$ brain scans was not thought to be an efficient method to substantially improve imaging health quality outcomes. ${ }^{19}$ However, these studies used unselected patients. Our higher rates of discrepancy from both MRI (brain and spine) and CT (brain) scans result from the selection of patients, mainly by neurology, for a neuroradiologist's report. This process appears to yield proportionately better diagnostic accuracy than unselected studies. A report from a Canadian tertiary referral centre for head and neck cancer found that management changed in more than one-third of patients following a neuroradiologist's second opinion review. ${ }^{20}$ This study and our study support the need for appropriate selection of patients for a second opinion service to be worthwhile.

Our DGH has a tradition of learning from feedback. ${ }^{21}$ The neuroimaging discrepancies are continuously fed back to the local radiology department and multidisciplinary meetings involving neurologists, neuroradiologists and general radiologists have evolved in an iterative process. The apparent lack of any improvement may have a number of contributing factors such as too many general radiologists reporting on too few patients with neuroimaging. Although somewhat speculative, this may cause spectrum bias, which is the performance of a diagnostic test according to the casemix of the population tested..$^{22}$ Casemix is a mixture 

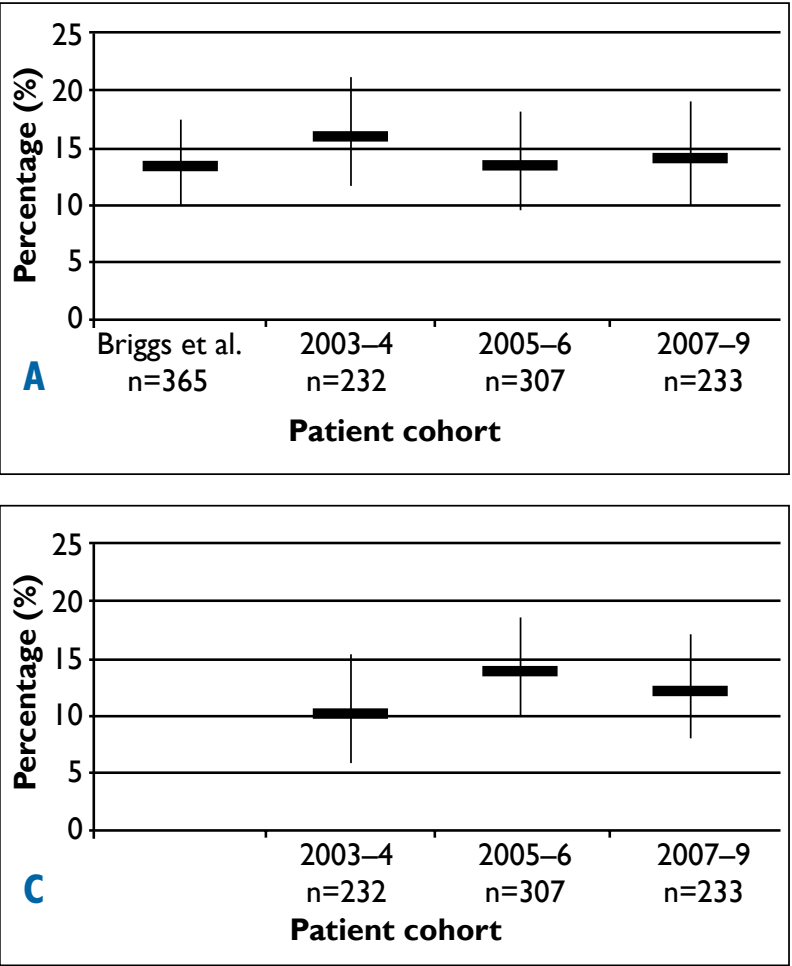

of disease severity and prevalence. In addition, our current real practice study was performed over 28 months, four months longer than our second study ${ }^{15}$ but had fewer patients. This may reflect improvement in that there was apparently less need to seek second reports from neuroradiologists. These issues highlight some of the complexities in demonstrating quality improvement in a neurological service; similar discrepancy rates may in fact hide increasing effectiveness of our developing service. The working experiences of the general radiologists and neuroradiologists were similar; all were NHS consultants. In addition, we previously demonstrated that rates of discrepancy reports were not significantly different among neuroradiologists at our tertiary centre or among general radiologists in our hospital. ${ }^{15}$

Previous reports have encouraged research into opportunities for improving healthcare other than focusing on death as an outcome. ${ }^{23}$ Others have recognised that internally-driven efforts may be required to demonstrate quality improvement. ${ }^{8}$ An improvement-focused culture is emerging ${ }^{4}$ and many radiologists believe that system improvements offer greatest quality benefits.'

Neurologists have to adapt to a changing work environment by contributing to robust audit measures with formative feedback to their multidisciplinary colleagues to improve service development. Neurologists can assist in clinical diagnostic accuracy ${ }^{12,24}$ and can shorten length of stay in a teaching hospital. ${ }^{25} \mathrm{~A}$ neurologist's effectiveness in this team approach requires further examination and refinement.

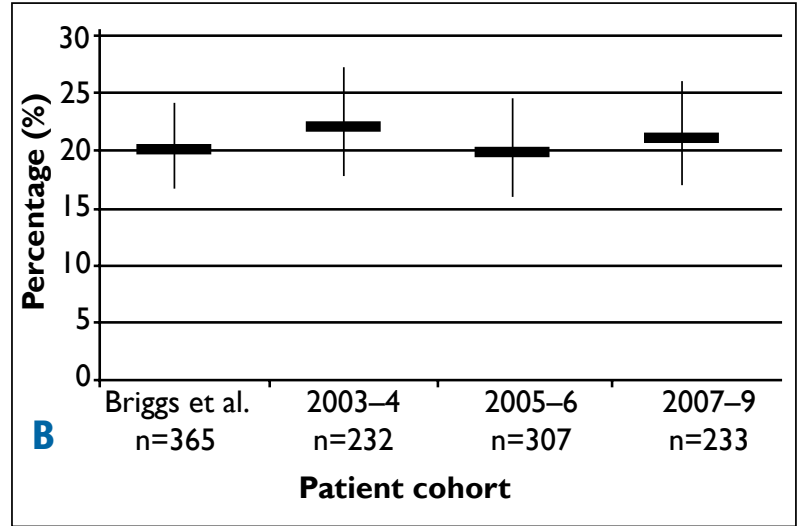

FIGURE 2A-C (A) Summary of primary diagnosis/ abnormality discrepancy rates, (B) secondary finding discrepancy rates, and (C) frequency of recommendations for further neuroradiological investigations in current and previous studies with $95 \%$ confidence intervals.

Limitations in our study include the lack of a gold standard in radiology. It is however accepted that the best available quality standard for neuroimaging is usually derived from neuroradiologists. Although a single centre study, our results have been validated in an independent study performed by neuroradiologists working in Northern Ireland using similar methodology. ${ }^{2}$ The high discrepancy rates in our studies may not only reflect our selection methods, but also previous under reporting of discrepancies within general radiology. Independent assessments are required to avoid bias, as previously demonstrated in carotid endartectomy surgery in which neurologists detected a higher rate of surgical complications than vascular surgeons. ${ }^{26}$ Our team approach is proving helpful in identifying not only reports of misinterpreted abnormal findings and reports of normal anatomy misinterpreted as abnormal, but has been particularly helpful for identifying missed lesions, which may not have been realised if selection for neuroradiologists' opinions had been restricted to general radiologists.

While double reading of mammography increases cancer detection rates, ${ }^{27}$ debate over second opinions in neuroradiology continues. In our neuroimaging study double reading by general radiologists may still incur discrepancy, although this was based on a sample that was too small to permit any further interpretation. Double reading of all neuroimaging scans by neuroradiologists has been deemed by some to be inefficient. $^{19}$ However, Zan et al. $^{3}$ argue that a neuroradiologist's review of outside studies benefits patients. They reported a $7.7 \%$ 'clinically important' discrepancy rate, most of which were discrepancies in detecting abnormalities rather than interpreting identified findings. Had our work involved consecutive unselected patients, we previously estimated a discrepancy rate in the primary diagnosis/abnormality to be around $6 \% .{ }^{14} \mathrm{~A}$ 
formal specialist second opinion has been recommended by neuroradiologists in Northern Ireland, but the selection criteria have not been clearly described. ${ }^{2}$ Both these studies represent a view from tertiary centres; development of local DGH services are required to maximise the diagnostic accuracy. Our studies of selective clinical audit at DGH level ${ }^{14,15}$ demand input from neurologists working with general radiologists and neuroradiologists to offer neurological patients better quality in the process of their overall local care. Quality control assessments among university-based neuroradiologists suggest a clinically significant discrepancy rate in both CT and MR imaging of $2 \% .^{10}$

\section{REFERENCES}

I Goddard P, Leslie A, Jones A et al. Error in radiology. Br J Radiol 200I; 74:949-5I.

2 Briggs GM, Flynn PA, Worthington $M$ et al. The role of specialist neuroradiology second opinion reporting: is there added value? Clin Radiol 2008; 63:79l-5. http://dx.doi.org/l0.1016/j. crad.2007.12.002

3 Zan E, Yousem DM, Carone $M$ et al. Second-opinion consultations in neuroradiology. Radiology 2010; 255:135-4I. http://dx.doi. org/ I0. I |48/radiol.0909083 I

4 Kaminski GM, Britto MT, Schoettker PJ et al. Developing capable quality improvement leaders. BMJ Qual Saf 2012;21:903-I I. http:// dx.doi.org/I0.I I36/bmjqs-2012-000890

5 Lilford RJ, Brown CA, Nicholl J. Use of process measures to monitor the quality of clinical practice. BMJ 2007; 335:648-50. http://dx.doi.org//0.1 I36/bmj.39317.64/296.AD

6 Bever CT, Holloway RG, Iverson DJ et al. Invited article. Neurology and quality improvement: an introduction. Neurology 2008; 70:163640. http://dx.doi.org/I0.12 I2/0I.wnl.00003 I0989.84987.88

7 Nicholl DJ, Yap CP, Cahill V et al. The TOS study: can we use our patients to help improve clinical assessment? J $R$ Coll Physicians Edinb 2012; 42:306-10. http://dx.doi.org/I0.4997/JRCPE.2012.405

8 Pronovost PJ, Hudson DW. Improving healthcare quality through organisational peer-to-peer assessment: lessons from the nuclear power industry. BMJ Qual Saf 2012; 21:872-5. http://dx.doi. org/I0.II36/bmjqs-20 I I-000470

9 Brady A, Laoide RO, McCarthy P et al. Discrepancy and error in radiology: concepts, causes and consequences. Ulster Med J 2012; 81:3-9.

10 Babiarz LS, Yousem DM. Quality control in neuroradiology: discrepancies in image interpretation among academic neuroradiologists. AJNR Am J Neuroradiol 2012; 33:37-42. http:// dx.doi.org/I 0.3 I 74/ajnr.A2704

I I Ross N, Parle J, Begg P et al. The case for the physician assistant Clin Med 2012; 12:200-6. http://dx.doi.org//0.786//clinmedicine 12-3-200

12 McColgan P, Carr AS, McCarron MO. The value of a liaison neurology service in a district general hospital. Postgrad Med J 20I I; 87:I66-9. http://dx.doi.org/I0.II36/pgmj.20I0.10697I

I3 Black N. Time for a new approach to assessing the quality of hospitals in England. BMJ 20 I 3;347:f442 I.http://dx.doi.org/ I 0. I I36/ bmj.f442I

14 McCarron MO, Sands C, McCarron P. Quality assurance of neuroradiology in a District General Hospital. QJM 2006; 99:I7I5. http://dx.doi.org/I0.1093/qjmed/hcl0I2

I5 McCarron MO, Sands C, McCarron P. Neuroimaging reports in a general hospital: results from a quality-improvement program. Clin Neurol Neurosurg 2010; II2:54-8. http://dx.doi.org//0.1016/j. clineuro.2009.10.009
Future areas of research and development should examine the effectiveness of double reporting of neuroimaging among general radiologists, efforts to minimise spectrum bias and the impact of local general radiologists with a special interest in neuroimaging. In this way robust local neuroimaging services can be further developed.

\section{Acknowledgements}

The authors are grateful to the many patients and colleagues in neuroradiology and general radiology, who assisted with this study.
16 CooperVF, Goodhartz LA, Nemcek AA Jr et al. Radiology resident interpretations of on-call imaging studies: the incidence of major discrepancies. Acad Radiol 2008; 15:1 198-204. http://dx.doi. org/I0.10I6/j.acra.2008.02.0II

17 Viertel VG, Babiarz LS, Carone $M$ et al. Quality control in neuroradiology: impact of trainees on discrepancy rates. AJNR Am J Neuroradiol 2012; 33:1032-6. http://dx.doi.org/I0.3I74/ajnr.A2933

18 Ruma J, Klein KA, Chong $S$ et al. Cross-sectional examination interpretation discrepancies between on-call diagnostic radiology residents and subspecialty faculty radiologists: analysis by imaging modality and subspecialty. J Am Coll Radiol 20I I; 8:409-14. http:// dx.doi.org/I0.1016/j.jacr.201 I.01.012

19 Jordan YJ, Jordan JE, Lightfoote JB et al. Quality outcomes of reinterpretation of brain $\mathrm{CT}$ studies by subspecialty experts in stroke imaging. AJR Am J Roentgenol 2012; 199:1365-70. http://dx. doi.org/I0.22I4/AJR.I I.8358

20 Lysack JT, Hoy M, Hudon ME et al. Impact of neuroradiologist second opinion on staging and management of head and neck cancer. J Otolaryngol Head Neck Surg 2013; 42:39. http://dx.doi. org/10.1186/1916-0216-42-39

21 O'Kane MJ, McManus P, McGowan N et al. Quality error rates in point-of-care testing. Clin Chem 201 I; 57:1267-7I. http://dx.doi. org/I0.1373/clinchem.20II.I645I7

22 Ransohoff DF, Feinstein AR. Problems of spectrum and bias in evaluating the efficacy of diagnostic tests. N Engl J Med 1978; 299:926-30. http://dx.doi.org/ I0.1056/NEJMI9781026299I705

23 Hogan H, Healey F, Neale G et al. Preventable deaths due to problems in care in English acute hospitals: a retrospective case record review study. BMJ Qual Saf 2012; 21:737-45. http://dx.doi. org/I0.II36/bmjqs-20 II-00II59

24 Douglas MR, Peake D, Sturman SG et al. The inpatient neurology consultation service: value and cost. Clin Med 201 I; II:215-7. http://dx.doi.org/I0.786I/clinmedicine.II-3-2I5

25 Forbes R, Craig J, Callender $M$ et al. Liaison neurology for acute medical admissions. Clin Med 2004; 4:290.http://dx.doi.org// 0.786 I/ clinmedicine.4-3-290

26 Rothwell PM, Slattery J, Warlow CP. A systematic review of the risks of stroke and death due to endarterectomy for symptomatic carotid stenosis. Stroke 1996; 27:260-5. http://dx.doi. org/I0.II6I/0I.STR.27.2.260

27 Helvie M. Improving mammographic interpretation: double reading and computer-aided diagnosis. Radiol Clin North Am 2007; 45:80II I. http://dx.doi.org//0.1016/j.rcl.2007.06.004 